\title{
The Role of Customary Conflict Resolution Mechanisms Among the Oromo: In Case of Dawo District of South West Shewa Zone
}

\author{
Kebede Lemu Bekelcha, Aregash Eticha Sefera \\ Department of Social Anthropology, Faculty of Social Sciences and Humanities, Bule Hora University, Bule Hora, Ethiopia \\ Email address: \\ kebedel2013@gmail.com (K. L. Bekelcha), aregash.kaliye2016@gmail.com (A. E. Sefera)

\section{To cite this article:} \\ Kebede Lemu Bekelcha, Aregash Eticha Sefera. The Role of Customary Conflict Resolution Mechanisms Among the Oromo: In Case of \\ Dawo District of South West Shewa Zone. Arabic Language, Literature \& Culture. Vol. 4, No. 2, 2019, pp. 32-40. \\ doi: 10.11648/j.allc.20190402.11
}

Received: June 22, 2019; Accepted: August 1, 2019; Published: September 23, 2019

\begin{abstract}
This study deals with the role of customary conflict resolution mechanisms in Oromia region with particular emphasis on Dawo district of south west shewa zone. Hence, the (i) purpose of this study was to examine and explore the significance of customary conflict resolution mechanisms in anthropological perspectives in the study area. The (ii) intent of the study was to identify the types of customary conflict resolution mechanisms and cause of conflict in Dawo district. The (iii) purpose of the study was to describe the structure and procedure as well as advantage and disadvantages of customary conflict resolution mechanisms. Finally, the purpose of this study was to provide information to understanding about the study area. To achieve this objective, both primary and secondary data was used. This study applied qualitative data. The data used in this study were generated from one- one interview, focus group discussion, case study and document analysis. In anthropological studies, analysis is an instrument to extract meanings from the information obtained during the field work. In such a manner, data were presented in a qualitative type. By using this methods, the study revealed that conflict in this research area emanate from land issues, theft and competition over resources.
\end{abstract}

Keywords: Conflict, Customary, Dawo, Conflict Resolution

\section{Introduction}

Conflict is not a recent phenomenon in human history. Rather, it is as old as human history. Since the appearances of human beings on this planet, they have been competing for resource and dominance. These controls of resources and dominance of one group over the others or one individual over the other create what conflict.

Conflict is a broad term and that is widely employed in scientific literature to indicate a state of disagreement or opposition [1]. Conflict is defined as disagreement or dissonance within or between social entities [2]. According to the study [3], conflict is a struggle over values or claims to status and scarce resources in which the aim of the conflicting parties is not only the desired values but also neutralizes, injures or eliminates their rivals. Conflict is an expression of the heterogeneity on interest between two or more individuals/groups [4].

The research [5] has stated that, it is from down of human history that communities have been competing for resource controls and dominance. These competitions inevitably led individuals as well as social, political, economic and religious groups to conflict. It is true that conflict would have devastating effects and it is undesirable. However, conflict is unavoidable and it has a character of persistence in one way or another.

No society in this world loves conflict. However, as long as people live together, work together, and interact with each other, disputes remain inevitable between sub-groups or individuals in a group, or between different groups. When these disputes are fuelled by emotion and become unsolvable, they develop into intra and inter-group conflicts. The source of the conflicts could be the incompatibility of the objective or subjective interests of the groups or individuals [6]. This implies that, in the interactions, one may violate the 
interest of the others and could cause damages to them.

The forms of conflict resolutions are likewise as diverse as those forms of social conflicts. The study [4] has identified a set of approaches that are applied to the resolution of conflicts. These are coercion, negotiation/bargaining, adjudication, mediations and arbitration. It [4] further categorize conflict resolution mechanism into two. These are the violent and the peaceful.

The violent include, war, self-help and duel, whereas the peaceful incorporated avoidance, burying the dispute in the symbolic process, negotiation, mediation, arbitration and adjudication. Usually, people have valid customs to manage conflicts in their societies.

The study [3] asserts that customs appears to exacerbate or restrain conflicts from destroying the fabric of social order. In societies where there are no offices with established authorities to control quarrels and to enforce formal laws, there were/are well-established and recognized codes or laws of convention and rituals. Relatively speaking, there are various indigenous conflict resolution mechanisms worldwide. Particularly, Africa which consisted multicultural, multi-ethnic, and multi-linguistics societies possessed various indigenous mechanisms of managing conflicts.

On the basis of a given belief in a given society, the conflicting parties are abided to be governed by their traditional codes. Ignoring these traditional laws would invite risks of exclusion from that society. Elders play a central role in these mechanisms, reconciling the conflicting groups according to the norms and forms prevalent in their respective areas [7].

Similarly, Ethiopia is a land of varied nations, nationalities and people possessed complex cultural make-ups in which each deserves its own peculiar cultural, socio-political and course of historical development [3, 8].

Among these diverse ethnic groups, Oromo is one of the Cushitic people and the largest ethnic entity in athe country [9]. Like other ethnic groups, Oromo people have their own indigenous conflict resolution mechanisms. Among these, Jaarsa Biyyaa institution (community elders), Qaalluu institution, Gumaa (blood compensation), and Seera Kakuu (law of oath) are practiced as mechanisms of conflict resolution in Dawo district, which is the subject of this research. Dawo district is located in south west shewa zone of Oromia National Regional State its capital is Busa town, located $96 \mathrm{~km}$ from Addis Ababa.

\subsection{Statement of the Problem}

Conflicts among the Oromo have been handled at the grass root levels by societies themselves by using several conflict resolution mechanisms. Oromo people for so long years have developed own unique political or administrative, economic, social, and judicial systems.

Similarly, the Dawo district people practice and use several customary conflict resolution mechanisms in order to solve conflicts which have occurred in social life, and to address the cause of conflict and seek to build solidarity, peaceful and good relationship within themselves and their neighboring societies. There is no anthropologist studied the area and role of conflict resolution mechanism of Dawo district here before. No attempts have been made to study of Jaarsummaa, Qaalluu, Kakuu and Gumaa in anthropological perspective in Dawo district. Therefore, the study's primary intention will be to fill these gaps and to increase the understanding of how the customary conflict resolution mechanisms manage the conflicts among the people of Dawo district.

\subsection{Research Questions}

I addressed the following questions in my research;

1) What are the causes of conflict in Dawo district?

2) What are the major customary mechanisms of resolving conflict in Dawo district?

3) What are the roles of customary conflict resolution mechanisms?

\subsection{Research Objectives}

\subsubsection{General Objective}

The general objective of the study was to examine the role of customary conflict resolution mechanisms in Dawo district a of Oromia national regional state.

\subsubsection{Specific Objectives}

The specific objectives of this research were;

1) To identify the causes of conflict in Dawo district.

2) To examine the types of customary conflict resolution mechanisms in the study area.

3) To find out the role of customary conflict resolution mechanisms in the study area.

\subsection{Significance of the Study}

The study may serve as useful input for those interested researchers to practice their studies on related topics. It may contribute to the understanding of the characteristics of these indigenous institutions of conflict resolution.

\subsection{Limitation of the Study}

I am an Oromo and a native speaker of Oromo language. Thus, I had no language constraints and culture barriers. Nevertheless, it does not mean that I accomplished my study without encountering any problem. Time constraint was the major problem. I only had one fieldwork which is too short time for an anthropological study. Hence, due to shortage of time in fieldwork, it was difficult to cover all kebeles in the district. Also, the translation of data from Afan Oromo to English was consumed more time and difficult task for me.

\section{Materials and Methods}

\subsection{Research Site}

Dawo district is one of the districts in south west shewa zone among the districts of south west shewa of Oromia 
regional state. Dawo district is bordered in the south west, by Waliso, in the west and north by Dendi, in the east by Elu and in the south east by Bacho. It lies between $8^{0} 45^{\prime} \mathrm{N}$ Latitudes and $38^{0} 10^{\prime} E$ Longitudes. The capital town of Dawo is Busa. Dawo district has estimated area of 426.88 square kilometers. It located 96 kilometers from Addis Ababa. Dawo has an estimated population density of 197 per kilometers [10].

\subsubsection{Demography}

According to [10], the total population of the district is 84,336 of whom 42,815 were men and 41,521 were women; 3,779 or $4.48 \%$ of its total population were urban dwellers.

\subsubsection{Climatic Conditions}

The study area is characterized by Baddaa (temperate), Badda-Daree (sub-tropical), and Gammoojjii (desert) climatic zones that account $45 \%, 40 \%$ and $15 \%$ of the district respectively. The two main rain seasons of the study area are summer and spring. The summer rain falls during June, July and August. The spring rain is from March to April. The mean annual rainfall of the district was estimated to be $800 \mathrm{~mm}$ - 1200mm/year (Source: Interview, May, 2019).

\subsubsection{Socio - Economic Conditions}

Agriculture is the dominant economic activities of the population of Dawo district. Among the primary economic activities, crop production and animal husbandry are the major ones. Due to its climatic diversification, the district is suitable for production of different kinds of crops. The most important crops grown in the area are wheat, barley, maize, teff, peas, beans, nug, sorghum etc. Among these, wheat, barley and teff are the most widely cultivated types of crops in Dawo district. Crop production is by large carried out using traditional farming system and traditional technologies. However, the use of modern mechanized tools such as Tractor and harvesting with Combiner is a recent practice. In addition, animal husbandry is also another major economic activities and source of income for both rural and urban population of Dawo district. This includes, rearing of cattle, sheep, goat, donkey and horses. However, the productivity of livestock is very low due to shortage of open field of grazing, lack of adequate veterinary services and animal rearing in general is mainly traditional focusing on quantity rather than quality of the animals. Trade also has a role as a source of income of the people of Dawo district (Source: Focus Group Discussion, May, 2019).

\subsubsection{Religions of the Study Area}

According to [10] report, the major religions practiced in the district were Orthodox Christianity (92\%), Protestant (3\%), Muslim (2\%) and Waaqeffannaa (3\%).

According to my informants, before the expansion of the modern religions such as Christianity and Islam, Oromo people had exclusively practiced their own believe system known as Waaqeffannaa. It is a form of traditional believes system where its practitioners believe in (God/creator). Due to the spread of Christianity and Islam, Waaqeffannaa has declined. However, now a time, the followers of this religion are increasing in the district and the religion is reviving.

\subsubsection{Ethnic Diversity of the Study Area}

According to [10] report, the two largest ethnic groups are Oromo (93\%) and Amhara (6\%) and the remaining one percent is other groups. In terms of language, Afan Oromo is spoken by $98 \%$ and Amharic is spoken by $2 \%$.

\subsubsection{Descent Organization Among the Dawo District Oromo}

Oromo people trace their descent in unilineal form known as patrilineal descent or through the fathers' line. Similarly, the Dawo district Oromo count their descent through their fathers' line. In this manner, they are organized into family, sub lineage, lineage, and clan. In this descent organization, family is the small unit of descent organization and easy for everyone to understand who belongs to whom. Sub lineage is the form of organization that constitutes a number of various families and also easy to understand each other.

The other descent organization of the Dawo district is lineage. It is a combination of different sub lineage. Hence, lineage is more complex form of descent organization than family and sub lineage. Clan is also a descent organization that people trace their descent. It is the most complex descent organization and difficult to understand each other than other descent organization. Because, clan is composed of different family, sub lineage and lineage.

\subsubsection{Marriage System of Dawo District}

Marriage has different rules in Dawo district and the day of the wedding ceremony is considered as exceptional day in the life of the bride and groom. There are six types of marriage practiced among Dawo district Oromo. These are Kaadhimmachuu (betrothal), Dhaala (inheritance), Abaabbaltii (marriage that takes place by convincing the bride without engaging the parents), Aseennaa (the situation in which girl enter the home of the man without his permission), Butii (abduction) and Irra dhaaba (marriage that takes places urgently without appointment).

Kaadhimmachuu is the most widely practiced type of marriage in Dawo district Oromo. This type of marriage is almost arranged by the parent's of the groom and bride through the mediation of elders. The boy's parents enquire Abba torba (seven generation) of the bride's family to make sure that families are not related by blood. If they are related to each other in less than seven generation, it is considered as haraamuu (incest taboo).

Aseennaa is a type of marriage which is common next to Kaadhimmachuu. This type of marriage is practiced by a girl whose marriages age her passed according to the local perception. Simply, when girl takes this form of marriage due to the following reasons. These are; when she goes beyond the standard of marriage set for girls as socially agreed upon, if she is not asked by for marriage anybody, when she is considered not beautiful and due to her family's social background.

Dhaala (Inheritance) type of marriage takes place between a woman whose husband has died and brother or relatives of 
the deceased husband. This is to maintain the family of the deceased man. The Abbaa Buddeenaa (step father) has high responsibility for that family. This type of marriage is practiced only one year after the death previous husband.

Abaabbalaa is another type of marriage in the district. According to this type of marriage, the groom and bride agreed to engage in marriage without prior knowledge of their parents. If the two agrees, the boy can take her when she is ready to do so. In most cases, the girl takes this form of marriage as a final option when her parents want to engage her to another boy whom she does not want.

Butii (abduction) is a type of marriage which is practiced by using force in this wereda rarely. This usually takes place when the boy is rejected by girl's parents, by girl herself and if he has economic problem to conduct formal marriage ceremony. One After the Butii takes place; the groom's family sends Jaarsa Araaraa (elders) to the bride's family to settle the matter.

Irra-dhaaba is indirectly it is a forceful marriage, which is practiced in a hurry. It is asking a girl for marriage which is done by breaching appointment arrangements or it is asking a girl for marriage without prior arrangement [11]. This marriage takes place in rare occasions. It takes place when the boy is from a socially despised group or when he is hand caped. The exceptional feature of this marriage is the girl and her parents do not have any prior knowledge until the boy accompanied by a group of men of different social classes arrive at the gate of the girl's parents.

\subsection{Data Collection Methods}

To collect data for this study, interview (unstructured interview), focus group discussion (FGD), and case study were employed to generate data from different sources. In addition to the primary data, secondary data was used.

\subsubsection{Interview (Unstructured Interview)}

I used as the preliminary data collecting methods to obtain relevant information. I also used interview to examine the people's attitudes towards indigenous conflict resolution and also to know the procedure of indigenous conflict resolution mechanisms which are being practiced in the study area. The interview involved different categories of people. Therefore, through this method, I got relevant information for this study.

\subsubsection{Case Study}

I also documented a number of different actual dispute cases that occurred in the study area in the last few years. Then, I identified dispute which was/were solved through Gumaa (blood compensation), Qaalluu institution, Seera Kakuu (law of oath), and Jaarsa Biyyaa institution. In all case materials, I used pseudo names for ethical reason

\subsubsection{Focus Group Discussion (FGD)}

It mainly helps generate additional information through discussions and the focus group discussion participants reminding each other. Therefore, I used this method to gather diverse information on advantages, disadvantages, and procedure of indigenous conflict resolution mechanisms. On these specific issues, different people may have different views. Thus, to look at views of different individuals and even to assess their level of understanding on this issues.

\subsubsection{Secondary Data}

Primary data need to be supported by previous research and other documents in order to make this research richer in data and strengthen the argument for its accomplishment. Hence, I used secondary data such as available books, proceedings, research reports, journals articles, newspapers, electronic materials and other relevant literatures on the indigenous conflict resolutions, and the people of the study area.

\subsubsection{Data Analysis}

Data analysis is one of the most important stages of any research. It is a step-by-step examination of issues and their connections. In anthropological studies, analysis is an instrument to extract meanings from the information obtained during the field work [12]. Any researcher has the responsibility of analyzing data to meet his/her objectives as well as to make the findings ready for scholarly consumption. The analysis is guided by the research questions and objectives. In general, the qualitative data of this study was presented in a descriptive form.

\section{Results and Discussion}

\subsection{Causes of Conflict}

There are multiple causes of conflict among Dawo district society. These are arising from economic, and social and cultural interactions.

\subsubsection{Conflict due to Land}

In Dawo district most of the time, conflicts are arise over land. These conflicts are conflict between households, neighborhood and neighboring communities' overland rights and boundaries, inheritance related conflicts among family members, and conflicts arising from household mobility, generational conflict over land use are common.

Land related conflict is divided into four categories. i) is caused by boundary trespassing. Most of the time, this kind of conflict occurred between two neighbors when one of the two trespass boundary of another. The community in the region use trees, ditch, small rivers and others to demarcate the boundary of their agricultural land. The symbols gradually may disappear due to natural force or by themselves. The disappearance of border demarcation brings boundary disagreement between individuals. Due to this reason, conflict would occur between the individuals. ii) is land related types of conflict because of the transfer of land. This type of conflict is corresponding to transfer of land from one person to another in the form of lease contract. People transfer their farm land to other people through local agreement for few years. Most of the time, people rent land to produce different cereals such as barley, wheat, maize, teff, and others. When the contract comes to end, there is a lack of 
willingness to return the land to its owner(s).

The giver and the contractor may dispute at the end of the day due to unwillingness to return the land to its owner(s). Third, conflict arises from inheritance. It is when unequal division of land carried between families members, conflict may occurs. It usually occurs when a husband has more than one wife. In this process of division of the land, one/more than two members of the family may not be satisfied. So, in this way conflict arise among the family members.

Fourth, the conflict may be arising when the land of individual is taken by the local authorities for different purposes. To sum up, land is the most frequent cause of conflict in Dawo district.

\subsubsection{Conflict Caused by Theft}

In Dawo district, illegal activities such as quarrel with each other and theft are predominant. The use of firearms for theft or for threatening people and slaughtering their cattle is illegal activity among the Oromo as a general and Dawo district as a particular. Most of the time, people involved in conflict due to theft when the person who lost his property suspect someone without certain evidence. During harvest and, mostly at the time of threshing the cereals might be lost in during the night and those who committed the theft remain unknown. When the individuals' belief that he/she can commit a theft without getting caught, they are more likely to steal more.

So, the community in the area uses the 'Jaarsa Biyyaa' (community elders) as well as traditional belief system in order to detect the wrong doer and reduce the tension before it escalates to conflict between individuals.

\subsubsection{Socio-cultural Based Conflict}

Socio-cultural conflict arises between individuals, groups and parties. When an individuals, groups or parties are prejudiced or threatened on the basis of their cultural practice, custom, religion, belief system, and clan. As a result of this, many people are labeled as child of witchcraft, child of weaver, child of evil eye, child of leaper, child of scratchier and child of smither. These types of connotation are the main factors for socio cultural based conflict in Dawo district.

\subsubsection{Marital Conflict}

Conflict some times, occur between the couples due to the ownership of property that they accumulate before and after get married. When such type of issue is present to the modern court, decision may be passed in unfair manner, if disputant parties have no evidence. For these reasons, someone is defeated at formal court on false witness in relation to ownership of property or other he/she could bring the case to the institution of traditional belief to get spiritual justice. Hence, at the institution the disputant would be gathered to swear in the name of Qaalluu institution and tell the truth. Thus, fair justice would be passed, conflict would be resolved.

\subsubsection{Conflict over Natural Resources}

It is among the basic source of conflict for Dawo district people. Hence, it creates high competition and tension over grazing land and water resource. The problem is even worse at the time of drought and famine in the area, which costs thousands of their livestock and compromises their survival as human being in the area.

\subsection{Customary Conflict Resolution Mechanisms in Dawo District}

\subsubsection{Jaarsa Biyyaa Institution}

The Oromo people in general and Dawo district in particular have a well-established culture and custom of resolving and preventing conflict called Jaarsummaa. Jaarsummaa is a traditional mediation by community elders, is a common method of conflict resolution that has been used across all Oromo clans. In Oromo society, almost all types of conflict were/are resolved through Jaarsummaa which is carried out by an institution called Jaarsa Biyyaa (community elders) or Jaarsa Araaraa (elders of reconciliation).

Jaarsa or Manguddoo literally 'old men' have moral responsibilities to settle conflicts and establish peace and security in their community. They are supposed to resolve any kind of conflict that may come across in their community. They either resolve it on the spot or fix a date, usually weekends or holidays to mediate the disputants. The term Jaarsa according to age grades of Gada system refers to an Oromo man whose age is 80. Jaarsa also means ones husband. But in the context of conflict resolution, in the term refers to any person (male) who participates in the process of settling dispute. It refers to the role of the person rather than his age [13]. The Jaarsa Biyyaa is literally elders of the country. However, the term Biyyaa in this context bears the meaning 'community' rather than its literal meaning 'country'. So, the term Jaarsa or Jaarsa Biyyaa refers to any adult with the role of resolving conflicts. Through Jaarsummaa, the Oromo people in general and Dawo district in particular have been resolving various types of interpersonal or intergroup conflicts ranging from minor clashes to violent conflicts which involve homicide.

The elders are often selected by the disputants or closer relatives of the disputants. Usually, the elders with good knowledge of the customary law and traditional norms of the society those with good reputation for their neutrality and rhetorical skills of persuasion are selected as Jaarsa Biyyaa or Jaarsa Araaraa. Especially, elders whose ancestors had once held a Gada office are often preferred for mediation because the decisions of such elders are often respected because they are believed to have good knowledge of the seera fi heera Oromo 'Oromo law and custom'. Generally, Jaarsa Biyyaa institution is the most widely used customary conflict resolution mechanism in Dawo district.

i. Selection Criteria of Jaarsa

Elders who participate in the Jaarsa Biyyaa institution have own criteria to be selected. Elders between 3- 6 will be selected for a single case. The criteria for selection are not age or kinship based. One criteria for selection is by virtue of 
his good reputation, his extensive and good knowledge of aadaa and seera 'custom and law of the Oromo. Individual talents and experience in dealing with conflict, altruism and willingness to give his time to reconcile the parties in dispute are also important factors for selection.

In addition, where possible, Dawo people choose Guulas (who passed in generation class of Gada system) especially for more serious matters. Guulas as legislators which are believed to have knowledge of the Oromo law and are responsible to restore peace and harmony in the community. It is also believed that Waaqa 'god' responds to the prayer and curse of Guulas.

Regarding the procedures of choosing elders, there are some steps.

1. Both parties may commonly choose whom they think are neutral and would handle their case efficiently and impartiality. The Dawo people call these elders as Jaarsa waltajjii (stage elders/common elders).

2. Each of the parties may nominate elders from their own side and comment on the nominee of the opposite side. In this procedure, the group to be set is the one in which both parties put their trust.

3. Both parties may independently choose their own Jaarsa whom they think would favor them. These elders are called Jaarsa bitaa fi mirgaa meaning 'the elders of the left and the right'.

4. A third party who is directly/indirectly concerned with a particular conflict may also select elders and take the initiatives for the reconciliation process.

ii. The Structure of Jaarsummaa

The elders are often selected on adhoc basis. However, among the Oromo such as Dawo district of the study area, there are individuals who are chosen permanently to give Jaarsummaa service. These elders are called Jaarsa Shanachaa (the fives of the lineage). These are selected by the community based on their skill to solving and managing the conflict. These elders have own place where they discuss with together on the issues of the community in every week or month. When the conflicts arise among/ between the parties, the disputants directly address their cases to the Jaarsa Shanachaa and resolve their conflict. In some part of Dawo district, there is no structured Jaarsa Biyyaa institution. That means, disputants call elders/people from their neighbor only when conflict occurred.

The other structure of Jaarsummaa is Jaarsa waaldaa (church elders). It plays great role especially among the followers of protestant Christianity in Dawo district. According to my informants, most of the time, Jaarsa waaldaa are odd in number. Because this odd number implies that when Jaarsa waaldaa want to decide on one issues of the society, the number of Jaarsa waaldaa who support and resist the issues are not equal. That means, the number of jaarsa waaldaa who support the issues may be less or more than the number of Jaarsa waaldaa who resist the issues to decide. But not equal. So, if they are not equal, it is comfortable to decide by majority vote.

If the numbers of Jaarsa waaldaa are even in number, the number of the supporter and who resist the issue may be the same. Hence, if their number is equal it will be difficult to decide by majority vote. Jaarsa waaldaa also do many things in the church of the followers of the religion. For instance, they give counseling service, settling conflict or dispute may occur in the church without going to formal court system and make different law regarding the societies of the protestant followers. Jaarsa waaldaa most of the time, do not punish the wrong doer rather than advising that person. However, if the wrong doer does not take the rule of the church, and resist it, the Jaarsa waaldaa pass decision like exclusion from the church.

Additionally, Jaarsa waaldaa also follow the family issues of the protestant societies. For instance, if dispute occurs in one family especially between husband and wife, the case directly go to the Jaarsa waaldaa rather than formal court. Then Jaarsa waaldaa settle their dispute by giving advice. Generally, Jaarsa waaldaa usually have their own plan and program to discuss on the issues of the protestant society and also have their own codified laws which govern and guide the society.

iii. The Procedures of Jaarsummaa

The Jaarsa Biyyaa is selected by the disputants (separately referred to as himataa (compliant) and himatamaa (defendant) or elders may take initiatives to solve the conflicts once cases are referred to them. Then, the elders first listen to what both parties have to say. Then, during Jaarsummaa session, the first turn is given to the compliant. Then, to the defendant. The turn-taking process is carefully managed and everybody is expected to talk only when he/she is given a chance from elders. Any kind of interruption by the disputants is punishable. The punishment is called Barcuma Jaarsa Kaasuu meaning 'stand the elder's chairs'. The elder's chair stands by paying money for the elders. Then, the elders contact others in the neighborhood of the disputants to verify necessary facts. Then, in the next meeting or the disputants are called separately and advised to compromise or it is known as maqoo. The wrong doing party would be advised to admit the offence and the truth to the other party, and the wrongdoer party also would be asked to give in some way to the offender in return for the truth, for the sake of the clan or the lineage and the elders, so that persistent hostilities are mitigated.

Among the Dawo district people, Jaarsummaa has four major phase; these are;

a) Dubbii banuu (Opening phase)

b) Waliif dhaggeeffachuu (Hearing)

c) Mariif maqoo (Discussion)

d) Araaraa (Reconciliation). These phases consist of several sequences.

Among the Dawo district, the opening phase of Jaarsummaa sessions often begins with the elder's eebba/kadhaa blessing and prayer' in Jaarsa Biyyaa institution of the Oromo as a general, blessing and prayer is a common cultural practice.

On hearing phase, the elders give a chance for the disputants to present their part of the case. Then, the 
disputants present their case without interrupting one another. The hearing is open to allow the disputants to cross examine each other to find out the truth. If the wrong doing party makes admissions without going to other procedures, the elders directly enter into discussion on how to reconcile the parties. If the defendant denies the claim, the case will proceed to the next step which is the evidence hearing process where the claimant will be asked to produce witnesses and/or other evidences. If the evidence by the claimant could not establish the truth about the defendant's commission of the said wrong, the defendants will be required to take kakuu (an oath).

Case I: Tola and Chala are living in Dawo district Dera Ilanso kebele. They are neighbors. Also, they have grazing land in common and used it together for a long period of time. In 2013 they disagree on the guarding of this land. Then, they decided to separate this land into two equal parts. They divided it by using the elders of the neighborhood. Then, they signed to approve their agreement in front of the elders. Tola changed his land to farming. But Chala uses his land as it is for grazing. Gradually, Tola trespassed the land of Chala. Then, Chala asked him "why you trespassed my boundary?" then, Tola did not accept the idea of the complaint. Then, Chala took the case to the elders who had divided the land. Then, when elders measured all of the land and again divided into two, they proved that Tola indeed trespassed the land of Chala. Then, elders reconciled by putting boundary for them.

\subsubsection{Kakaa (Oath)}

Kakaa is one of the mechanisms of conflict resolution in Dawo district. It is considered to be very dangerous mechanism and what to be taken if someone has committed the crime. The main purpose of taking an oath is to justify whether an individual is free from the act or not. Kakaa can be taken using material cultural objects prepared for such purposes such as ash and knife. The assumption is that if the defendant accepts to take a Kakaa, it means that he was not the wrong doer. But if the real wrongdoer is found out by this process, the elders will proceed to redressing the claimant and consolidate the reconciliation process. Depending on the nature of conflict, the wrongdoer would be made to pay compensation or do other things as found commensurate to the wrong done.

Case II: Gabi is living in Dawo district Sedare Arbu where the dense forest of the wereda is located. In 2013 his two sheep were lost in this forest. Searched for a week but could not get his sheep. There is a well known thief that is known by the society in the village. His name is Teman. Then, Gabi suspected Teman for his sheep. Now, he has no evidence rather than suspicion him. Then, Gabi decided to take Teman to Kakaa. Then, Gabi took a case into elders who permanently give this service. Then, elders command Teman to call six relatives both from his father and mother side as well as from neighbors who swear to purify him from this case. After two weeks, his relatives came and spurn to swear for him. According to Seera Kakaa (oath law), if once relatives refuse to swear for somebody, that person will be considered as wrongdoer. In this case, all Teman relatives and neighbors reject to swear for him and Teman considered as a thief. Then, Teman accepted what elders decided to pay for Gabi and also paid some amount of money that is locally decided for the elders.

\subsubsection{The Qaalluu Institution}

Qaalluu institution is one of the mechanisms of conflict resolution and maintains social orders. Qaalluu institutions also resolve often difficult conflicts through the process of mediation and adjudication. It is based on sprit possession mediumship. The Qaalluu is a person who serves as a medium for the Ayyana (sprit) and is believed to have a capacity to communicate with Waaqa (God). The Qaalluu is believed to be a spiritual leader who has Ayyana (sprit). The Ayyana dwell in the individual Qaalluu and speaks through his mouth during possession. Both are inseparable. It serves as an intermediary between the human and the Ayyana (sprit). In most cases the Qaalluu inherits the position and capacity from his forefathers.

The Qaalluu adjudicates alongside the Jaarsa Araaraa (the elders of reconciliation) cases may be taken to the Qaalluu if the elders are unable to solve the cases or if it relates to ritual cases such as ritual appeasement or rifting of curses or serious matters. The Qaalluu has sufficient authority to render his decisions effective and definitive. The institution has the jurisdiction to pass judgment upon any kind of matter from simple cases to homicide. In Qaalluu court, either the Qaalluu himself serves as a judge/mediator or appoints honest and wise elders of the community. These elders are called Jaarsa Yaboo and often permanently serve in a given Qaalluu institution. The Qaalluu proceedings are held in Qaalluu ritual center known as Galma (Qaalluu's site).

People take their cases to Qaalluu on two occasions;

1. When disputants are not happy with the outcome of the mediation by the community elders.

2. When disputants could not come up with sufficient evidence to substantiate their claim in which case, the Qaalluu summons the respect and make him/her prove his/her innocence by taking an oath.

Qaalluu courts are often considered supreme and disputants often accept their decisions and speak the truth mainly for fear of punishment arising from the spirit of the Qaalluu. Additionally, this institution also works with the primary goal of creating reconciliation and forgiveness and removing the feeling of enmity between disputants. The Qaalluu institution still serves as a mechanism of conflict resolution among the Oromo people in general and Dawo district in particular.

i. The Selection of Jaarsa Yaboo

In Qaalluu institution, the selection of Jaarsa Yaboo has its own criteria. These are personal relationship with the Qaalluu, one's good reputation; wisdom, honesty, thoughtfulness, and willingness to serve at Qaalluu court come into play in choosing the Yaboo elders. Sometimes 
Qaalluu himself acts as Jaarsa Yaboo.

ii. Types and Context of the Cases of Qaalluu Institution

The cases appealed to Qaalluu if the injured parties are unable to testify the truth of the case or if the Jaarsummaa system bears no fruit. The Qaalluu never dismisses a case on the ground that the evidence is not conclusive enough. The defendant possibly proves his innocence through oath in the absence of any witness. The failure or refusal to take oath to prove one's own innocence is an indication that the person is guilty.

Case III: Tamasgen is living in Dawo district Gombisa Kusaye kebele. In 2014, his horse was stolen by somebody. He searched here and there and was not enable to get it. He went everywhere in Dawo district, Bacho wereda and even some part of Saden Soddo to search his horse. He did not get it. A year before, he clashed with a person named Ahmed in this kebele. Hence, Tamasgen suspected Ahmed for the case. Then, Tamasgen called him to Qaalluu institution named Warra Haadha Goraa. In Dawo district, this Qaalluu institution won respect and considered as dangerous. Then, Ahmed went to the Warra Haadha Goraa Qaalluu institution with Tamasgen. Then, Ahmed accepted that he stole Tamasgen's horse. Then, the Qaalluu institution passed a punishment/fine on Ahmed to pay an estimate price of the horse and fine for Qaalluu institution. Then, Ahmed accepted the decision of Qaalluu institution to pay all compensation. Then, the Qaalluu institution reconciled them so that they have long lasting relations with each other.

\subsubsection{Gumaa (Blood Compensation)}

Gumaa is one of the customary conflict resolution mechanisms. It is highly procedural and has elaborate ritual mechanism of resolving conflicts related to murder. The term Gumaa refers to the general institution of settling blood feuds between two persons, families, groups, clans and communities. The word loosely used for different concepts. For the speaker of Afan Oromo, the term has the meaning of vendetta, vengeance and revenge. Gumaan koo hin haftu literally means my Gumaa would not remain'; contextually, it means I would revenge. Gumaa also refers to blood price or compensation that follows homicide or serious bodily injuries. Gumaa baasan meaning they paid blood price and Gumaa fudhatan meaning they received blood price. Also Gumaa is employed to mean feud. Nuti warra gumaati meaning we are in feud with them.

Similarly, it refers to the ritual of purification that follows homicide/body injures. The term also has the meaning of the things. For instance, midhaan Gumaa tokkoo hin qabu meaning I do not have even a grain. Gumaa further has the meaning of pupil. Gumaa ija isaatu bade meaning he lost the pupil of his eye.

However, throughout this senior essay, I strictly employed it as a mechanism of conflict resolution. In this type of conflict resolution, the offender pays compensation or blood price for the victim's parents or relatives and officially apologies to the relatives of the victim. Gumaa also refers to the type of offence. Among Oromo, offences that cause bleeding or lose of one's body party and cause death are considered as Gumaa.

Case: Guluma is living in Dawo district Rache Kusho kebele. In 2012 he clashed with a person whose farm land is near his farmland. His name is G/Mikael. For a long time, they disagree on their boundary of farmland and they reconciled by elders frequently. Then, Guluma one day sowed seed by trespassing the boundary of G/Mikael. After four days, G/Mikael turn over the seed of Guluma. Then, Guluma heard the act of G/Mikael from his children. Then, Guluma took pistol and shoot G/Mikael and killed him. Guluma then vanished to somewhere. Then, the clan of Guluma started to requesting G/Mikael's clan to accept blood compensation by sitting on a place where they can be seen by other Tulluu Rache (a mountain which is found in Dawo district). Guluma's clan continued their request for eight months. Finally, the G/Mikael's clan offered to reconcile. Then, Guluma's clan and G/Mikael clan's represented own mediators for flow of information between the clans. After three weeks, they fixed a day of reconciliation. Then, the mediators of two clans bought a sheep which has only one color. The mediators of the clans as well as other members went to the river and they stood opposite of each other. Then, the representatives of each clan come together in the middle of the river with sheep. Then, they pierce the belly of the sheep alive. Then, they exchanged grass through the abdomen of the sheep and spread the blood of the sheep with grass to own clans. Then, they threw the sheep to the river and went to the house with together. Then, they started to eat from one maaddii (dish).

\section{Conclusion}

In this world, there is no society who loves conflict and also no one can live alone. However, as a result of day-to-day interaction process, conflict would be occurred. It occurs whenever people disagree over their values, motivation, perceptions, ideas or desires. Regarding the concept of conflict, there are many theories like individual characteristics theories, social process theories, social structural theory, structural functional theory and game theory. Each of these theories has their own perspectives that shape the causes and definition of the term conflict. Beside the occurrence of conflict, human beings use different mechanisms like mediation, adjudication, negotiation, separation/avoidance to fully resolved whenever they occur or prevent them from further escalating. The ways of conflict resolution is always deals with the root cause of conflict and eliminating them by altering and restructuring the institutions forces and systems that perpetuate such conflict or simply when the root causes of that particular conflict are identified and addressed.

Most of the time, conflicts are resolved through customary conflict resolution mechanisms which comprise social, economic, cultural and religious spiritual dimensions in accordance with the entirety of traditions, customs and world views of a society within the different sphere of societal life. Hence, customary methods are holistic and consensus based and often involves the participation of all parties as well as 
the entire community. These customary conflict resolutions mechanisms have their own advantages and disadvantages. For instance, like minimize the shortage of judges who works in regular courts and budget constraints, cultural relevance are some of their advantages and abuse of power, lack of accountability are shortcomings of these mechanisms. These customary conflict resolution mechanisms are well known in Ethiopia. Most of nation, nationalities and peoples of Ethiopia have developed widely and effectively used customary conflict resolution mechanisms for the prevention and resolution of conflicts.

Particularly, among the Oromo, Amhara, Tigre, Gurage, Afar, Kembata and the like are widely used customary conflict resolution mechanisms. Among the Oromo, there are various customary conflict resolution mechanisms like Jaarsa Biyyaa/Jaarsummaa institution (community elders), Qaalluu institution, Gumaa (blood compensation), Kakaa (oath). These mechanisms are use to manage conflicts on three different levels. These are; to prevent conflict from occurring; if it might occur, to prevent escalation; if it escalates, to make peace between the parties through intervention of third party.

Similarly, in Dawo district which located in south west shewa zone of Oromia regional state, there are various customary conflict resolution mechanisms which people use in their daily life to settle or resolve conflict. These mechanisms are; Jaarsa Biyyaa (community elders), Qaalluu institution, Kakaa (oath), Gumaa (blood compensation). All these mechanisms have their own structure and procedure when they are apply to resolve conflicts.

\section{Acknowledgements}

I would also like to thank Dawo wereda elders and other informants who attained my interview and focus group discussion up to end. Next to these, I would like to extend my appreciation for all people who helped me in providing materials, giving suggestion and comment and editing my study. Finally, I would like to extend my appreciation for some special people in my life. I am very grateful to my families and friends especially my mother Disatu Berisa and my father Lemu Bekelcha, my wife Aregash Eticha (Hareg!) and also my brother Reporter Teshome Lemu for standing beside me and motivating me in my study.

\section{References}

[1] Kriesberg, Louis (1996). Social Conflict: in the social science encyclopedia: London: Rutledge.
[2] Assefa, Abebe (2001). Indigenous Mechanisms for the Presentation and Restoration of Conflict: the experience of Oromo in Ethiopia: paper presented to the work shop on conflict in the horn: presentation and resolution: organized by OSSREA; Addis Ababa: Ethiopia.

[3] Abebe Demewoz, Samson Seid and Tessema Gebre (2015). Indigenous Conflict Resolution Mechanisms among the Kembata Society: American Journal of Educational Research, 2015, Vol. 3, No. 2, 225-242: Science and Education Publishing.

[4] Schellerberg, James (1996). Conflict Resolution: Theory, Research and Practice: Albany: State University of Newyork Press.

[5] Pruitt, D. G (2001). Conflict and Conflict Resonation: Social Psychology: in international encyclopedia of the social and behavioral science: Amsterdam: Elsevier Science ltd.

[6] Fetherston, A. B (2000). From Conflict Resolution to Transformative Peace Building: reflection from Croatia Centre for conflict resolution: department of peace studies: Bradford University.

[7] Dejene Gemechu (2002). Some Aspects of Conflict and Conflict Resolution among Waliso Oromo of Eastern Macha, With Particular Emphasis on the Guma (MA Thesis): Addis Ababa University: Ethiopia.

[8] Giday, Degefu (2000). In Introductory Inquiry into the Salient Features of Traditional Mechanisms of Conflict Resolution in Gurage, Amhara, Oromo, and Tigre Societies: Ethiopian International Institute for Peace and Development (EIIP) press: Ethiopia.

[9] Dejene Aredo and Abdurahman Ame. 2005. Indigenous resolution in pastoral Areas of Ethiopia: The case of the well council and Arara of Borena. Research report, Organization for Social Science Research in Eastern and southern Africa (OSSRESA). Addis Ababa.

[10] Population and Housing Census of Ethiopia (2007): Results for Oromia Region.

[11] Gemechu, Beyene and Assefa, Tolera (2006). Marriage Practices Among the Gidda Oromo, Northern Wollega, Ethiopia: Nordic Journal of African Studies 15 (3): 240-255 (2006).

[12] Teshome, Emana (2014). The Transforming Power of Urbanization: Changes and Uncertainties among the Farming Community in Laga Xafo-Laga Dadhi Town, Ethiopia (PhD Dissertation): Addis Ababa University: Ethiopia.

[13] Alemu, Disassa (2013). A Discourse Analysis of Jaarsummaa; A Traditional Method of Dispute Resolution by the Community Elders: Arsi Oromo in focus: Addis Ababa University. 